Brigham Young University Law School BYU Law Digital Commons

Faculty Scholarship

$12-31-2006$

\title{
Blogging While Untenured and Other Extreme Sports
}

\author{
A. Christine Hurt \\ BYU Law School, hurtc@law.byu.edu \\ Tung Yin
}

Follow this and additional works at: https://digitalcommons.law.byu.edu/faculty_scholarship

Part of the Legal Writing and Research Commons

\section{Recommended Citation}

A. Christine Hurt \& Tung Yin, Blogging While Untenured and Other Extreme Sports, 84 WASH. U. L. ReV. 1235 (2006).

This Article is brought to you for free and open access by BYU Law Digital Commons. It has been accepted for inclusion in Faculty Scholarship by an authorized administrator of BYU Law Digital Commons. For more information, please contact hunterlawlibrary@byu.edu. 


\title{
BLOGGING WHILE UNTENURED AND OTHER EXTREME SPORTS
}

\author{
CHRISTINE HURT* \\ TUNG YIN ${ }^{* *}$
}

\section{INTRODUCTION}

According to Dan Solove's March 2006 Law Professor Blogger Census (Version 4.3), roughly twenty-one percent of law professor bloggers in tenure-eligible positions ${ }^{1}$ are untenured, or as the authors here prefer, "pretenured." The percentage of professors blogging who are pretenured, as opposed to tenured, is higher than the percentage of pretenured professors in the profession, ${ }^{2}$ so one might argue that the pretenured are overrepresented in the blogosphere. ${ }^{3}$ Pretenured academics may gravitate easily toward blogging for many reasons. Junior professors are likely to be younger and, as such, likely to be more familiar with and willing to

* Associate Professor of Law and Richard W. and Marie L. Corman Scholar, University of Illinois College of Law. I am fortunate to be a blogger at Conglomerate, www.theconglomerate.org, a group blog with personality that is broadly focused on business, law, economics, and society.

** Associate Professor of Law, University of Iowa College of Law. Blogging since 2004 at the Yin Blog, http:/yin.typepad.com (and before that at a different, now-defunct address), and since 2006 at National Security Advisors, http://www.natseclaw.com.

1. Posting of Daniel Solove to Concurring Opinions, http://www.concurringopinions.com archives/2006/03/law_professor_b_4.html (Mar. 15, 2006, 11:06 p.m.) [hereinafter Census 4.3]. For purposes of this statistic, we have counted only bloggers who are in a position that may be tenured. Bloggers who teach in positions that are not eligible for tenure were not counted as either "tenured" or "pretenured." In addition, librarians and clinical faculty, who may be eligible for a different institutional tenure, were not counted as either "tenured" or "pretenured." However, some of the discussions herein with respect to the risks and rewards of blogging will also be applicable to these bloggers, who may teach under short- or long-term contracts awarded at the discretion of the Dean or a faculty committee.

2. Association of American Law Schools, Statistical Report on Law School Faculty and Candidates for Law Faculty Positions Tables 2005-2006, http:/www.aals.org/documents/statistics/ 20052006statisticsonlawfaculty.pdf (last visited Jan. 29, 2007) (showing that assistant professors constitute approximately eleven percent of tenure-track faculty at AALS member schools and associate professors, many of whom are tenured, constitute $17.5 \%$ ).

3. This statement should not imply, however, that even a substantial percentage of pretenured law professors, or of all law professors, blog. Approximately $5.6 \%$ of assistant professors blog, and a little more than three percent of all professors blog. Compare id. (reflecting 709 assistant professors in law teaching and 6409 tenure-track or tenured professors) with Census 4.3 , supra note 1 (listing fortyone law bloggers who are listed at their schools as assistant professors and 214 tenure-track or tenured bloggers). 
embrace new technologies. ${ }^{4}$ New professors, fresh out of clerkships and degree programs, may be used to living their lives in the vicinity of a laptop and an Internet feed. In addition, because the market for entry-level law professors has become so competitive, new professors are almost by definition writers. In order to secure their placements, these overachievers have used most of their free time researching and writing; therefore, continuing to do so in a blog format, once teaching and scholarship becomes a day job, may seem only natural. Although this infusion of energy in the blogosphere from the junior faculty may seem laudable, well-meaning mentors may caution pretenured faculty to refrain from blogging. In fact, conventional wisdom seems to warn that blogging may be a risky venture for those academic bloggers who have not been awarded tenure and the liberating academic freedom that comes with that status.

Most agree that pretenured blogging involves inherent risks, such as inadvertently (or purposefully) being offensive, insulting, misunderstood, insensitive, or just wrong. In this view, a pretenured faculty member has little to gain from blogging and has much to lose. Blogging does not seem to fall into any of the three primary categories used to assess tenure candidates (scholarship, teaching, and service), although it will take time away from all three. However, if blogging while pretenured is such an unwarranted risk, then we must find an explanation for the high number of pretenured bloggers.

Although the risks to pretenured bloggers are real, the benefits may far outweigh the risks for many junior professors. Depending on the kind of exposure and support available to a junior professor at her home school, blogging may be the best way to gain exposure for one's work, find mentors, and engage in iterative discussions on relevant topics. However, pretenured professors should be aware of the risks of blogging and develop strategies to avoid or mitigate the pitfalls of blogging without a tenure net.

\section{THE CONVENTIONAL WISDOM}

Both at the 2006 Association of American Law Schools conference panel "Blogging: Scholarship or Distraction?" and afterward on various blogs, commentators expressed reservations about pretenured blogging. At the panel, Randy Barnett, of The Volokh Conspiracy, was the most

4. A parallel hypothesis would suggest that pretenured faculty are also overrepresented on SSRN or use ExpressO in greater percentages than the tenured faculty. As ambitious as we are, we are not ambitious enough to gather that data at this point. 
outspoken opponent of pretenured blogging; however, he qualified his reservations both during the question-and-answer period and in a subsequent blog post. ${ }^{5}$ Though Professor Barnett acknowledged that the benefits of blogging inure to all law professors, he emphasized that some risks apply particularly to the pretenured, including the following two risks:

(1) Potential negative reaction by tenured faculty to one's opinions. This is especially true of opinions that run to the left or right of the bulk of the faculty.

(2) The risk of distraction from the long-form scholarship that leads to tenure and, more importantly, generates the knowledge that makes one a genuine scholar rather than solely a polemicist or pundit. $^{6}$

The other tenured speaker at the panel, Lawrence Solum, also cautioned pretenured bloggers about the hazards of blogging: "If you say something intemperate, ill-informed, or offensive on a blog, it may create a lasting negative impression. This is not speculation. I know of more than one academic blogger - both senior and junior - who has prompted multiple negative remarks."?

This risk aversion toward pretenured blogging is not limited to legal academia. Academics in other departments have discovered blogging, and the reaction has also been mixed. A Chronicle of Higher Education article described the dangers of being a job candidate for a tenure-track job with an accessible blog. ${ }^{8}$ This article revealed that hiring committees see blogging as a negative if the posts reveal that the author is more interested in a field other than his research agenda, that the author likes to blog about his personal life, that the author uses a blog as a therapeutic outlet, or that the author blogs to vent about politics or daily life. For would-be employers, "too much information" may be off-putting:

It would never occur to the committee to ask what a candidate thinks about certain people's choice of fashion or body adornment, which countries we should invade, what should be done to drivers

5. Posting of Randy Barnett to Volokh Conspiracy, http://volokh.com/archives/archive_2006_ 01_08-2006_01_14.shtml\#1136820752 (Jan.9, 2006, 9:32 a.m.).

6. Id.

7. Posting of Lawrence Solum to Legal Theory Blog, http://solum.blogspot.com/archives/ 2006_01_01_lsolum_archive.html\# 113683990156732487 (Jan. 9, 2006, 5:20 p.m.).

8. Ivan Tribble, Bloggers Need Not Apply, CHRON. HIGHER EDUC., July 8, 2005, at C3. 
who refuse to get out of the passing lane, what constitutes a real man, or how the recovery process from one's childhood traumas is going. ${ }^{9}$

Although job candidates face tougher odds of finding a tenure-track position than most law professors do of being granted tenure, the caution may also apply to pretenured law bloggers. Particularly in an environment where virtually all law schools, regardless of rank, are pressuring junior scholars to publish, any activity that systematically takes time away from scholarship may be dangerous. ${ }^{10}$ As any blogger will admit, blogging can be highly addictive. ${ }^{11}$ Time each day may be spent reading other blogs and online news for blog fodder, posting thoughts on these developments, checking traffic statistics of the blog, checking to see if other blogs have linked to your blog, reading comments, responding to comments, commenting on other blogs, and even tinkering with your site.

The quintessential cautionary tale for pretenured bloggers is that of Daniel Drezner, ${ }^{12}$ an untenured political scientist at the University of Chicago. Drezner began his first post, entitled Here Goes Nothing, on DanielDrezner.com with the words "I shouldn't be doing this. I'11 be going up for tenure soon; I occasionally daydream of occupying a high position in government; and I like semicolons way too much to be pithy."13 Three years later, after amassing a substantial following for his blog, which was much more serious and analytical than personal, ranting or tangential, ${ }^{14}$ Drezner was denied tenure at Chicago. ${ }^{15}$ Although Drezner hypothesized on his blog that in the absence of blogging he may have produced more or

9. $I d$.

10. But see Posting of Larry Ribstein to Ideoblog, http://busmovie.typepad.com/ideoblog/2006/ 01/bloggin_distra.html (Jan. 9, 2006, 6:30 a.m.) (arguing that high-level scholarship can only be produced in a finite number of hours of most scholars' days, so blogging may therefore only poach from the "lower-value end of scholarship time").

11. Posting of Daniel Solove to Concurring Opinions, http://www.concurringopinions.com/ archives/2005/10/a_day_in_the_li.html (Oct. 18, 2005, 12:01 a.m.) (detailing the unenviable life of a blogger who spends every minute of each day checking the blog, checking e-mail, checking sitemeter, checking Technorati, and repeating these consuming tasks).

12. Robert S. Boynton, Attack of the Career-Killing Blogs, SLATE, Nov. 16, 2005 , http://www.slate.com/id/2130466/.

13. Daniel W. Drezner, http://www.danieldrezner.com/archives/000623.html (Sept. 10, 2002, 11:17 a.m.).

14. See Boynton, supra note $12("[\mathrm{H}] \mathrm{e}$ usually writes about globalization and political economy - the very subjects on which he publishes in prestigious, peer-reviewed presses and journals. If his prose style in the blog is more engaging than that of the typical academic's, the thinking behind it is no less rigorous or intelligent.").

15. Daniel W. Drezner, http://www.danieldrezner.com/archives/002353.html (Oct. 8, 2005, 10:20 p.m.). 
better scholarship, he was not sure that the other benefits of blogging were outweighed by this possible opportunity cost. ${ }^{16}$ These other benefits, which Drezner had described as doors that had opened, may have assisted in his soft landing; ${ }^{17}$ Drezner announced less than a month later that he had accepted a tenured position at Tufts University. ${ }^{18}$ However, blogospheric commentary revealed that Drezner was not the only Chicago blogger denied tenure in the 2005-06 year. ${ }^{19}$

Drezner opined that neither he nor his colleague were denied tenure for saying anything controversial on their blogs. If blogging were perceived as a negative by their institution, this negativity may have been an innocent belief that the prolific bloggers should have been using that time more productively, even if their scholarly output seemed unaffected. ${ }^{20}$

In addition, criticisms of pretenured blogging may even be pretextual, albeit effective, arguments against a new technology that threatens to subvert existing law school hierarchies that differentiate among faculty classes and among faculties at various law schools. ${ }^{21}$ If this is true, then even the most reasonable and intellectual of bloggers may generate ill will among members of the home faculty, regardless of the quality of the blog in question. And, as Ann Althouse has theorized, nonblogging academics may be opposed to having academic blogging be seen as a positive, because if blogging is positive, it may soon be required:

One thing missing from this article is the recognition of the fear nonblogging academics have about bloggers. For one thing, they don't understand what the bloggers are doing and worry that we'll

16. $I d$.

17. Scott Jaschik, Too Much Information?, INSIDE HigHeR EduC., Oct. 11, 2005, $\mathrm{http}: / /$ insidehighered.com/news/2005/10/11/bloggers ("One of the advantages of the blog is that I knew that a lot of people in my field read it and this was the best way to advertise that I'm on the market.") (quoting Drezner).

18. Daniel W. Drezner, http://www.danieldrezner.com/archives/002395.html (Nov. 5, 2005, 8:48 a.m.).

19. See Jaschik, supra note 17 (reporting that Sean Carroll, who blogged at Proposterous Universe, was denied tenure by the physics department). Professor Carroll, who now blogs at Cosmic Variance, announced on April 6,2006, that he had accepted a research professor appointment at the California Institute of Technology. See Posting of Sean Carroll to Cosmic Variance, http://cosmicvariance.com/2006/04/06/going-to-california/ (Apr. 6, 2006, 6:08 p.m.).

20. See Jaschik, supra note 17 (quoting a "tenure coach" for academics as warning that others who do not blog may assume that bloggers spend an inordinate amount of time on a blog, even if that is not the case).

21. See Franklin G. Snyder, Late Night Thoughts on Blogging While Reading Duncan Kennedy's "Legal Education and the Reproduction of Hierarchy" in an Arkansas Motel Room (Apr. 11, 2006), available at http:/papers.ssm.com/sol3/papers.cfm?abstract_id=894957 (hypothesizing that part of the hostile reaction to pretenured bloggers comes from "the defenders of the hierarchies"). 
do something damaging or dangerous with our power (such as it is!). But they also don't want to know that it's good, because that unleashes the other fear: Will I be required to blog? If blogging is good, are they going to be judged deficient for not blogging[?] And they are probably already at least a little jealous about their colleague's heightened profile. It seems a little unfair that the ability [to] translate expertise into blog form brings prominence that nothing ensures will be proportionate to the quality of the traditional written research. Of course, the actual quality of the traditional research has never been precisely calibrated to an academic's prominence, but blogging lets different individuals use different paths to prominence. Most notably, it gives new power to persons who don't teach at elite schools and don't have elite connections. It's a new way to get connected. It's threatening! And since it may be intertwined with political power and a kind of pop culture celebrity, it can be infuriating! $!^{22}$

Therefore, one of the unpreventable dangers of blogging may be offending those nonblogging professors who prefer academia's traditional methods of creating, disseminating, and discussing scholarship. ${ }^{23}$ At the same time, the existence of a critical mass of pretenured bloggers, coupled with a trend toward more and more law professor bloggers, may mean that anti-technology-based objections will be less tenable in the near future.

Of course, for every highly publicized example of a blogger being denied tenure, there are quieter examples of bloggers being granted tenure. $^{24}$ In addition, though observers have difficulty pinpointing blogging as the reason for a positive or negative tenure vote out of many soft factors, observers may validly infer that other types of career successes obtained by junior faculty are attributable to blogging, such as conference invitations or lateral offers. ${ }^{25}$

22. Althouse, http:/althouse.blogspot.com/2005/11/academic-blog-controversies.html (Nov. 16, 2005, 7:26 a.m.).

23. See Posting of Larry Ribstein to Ideoblog, http:/busmovie.typepad.com/ideoblog/2005/10/ blogging tenure.html (Oct. 11, 2005, 10:24 a.m.) ("If blogging emerges as a new standard for academic success, this could invade the quiet life of the ivory tower.").

24. See Althouse, supra note 22 (noting that Brian Weatherson of Thoughts, Arguments and Rants had been granted tenure at Cornell University and that Jeremy Freese, of Jeremy Freese's Weblog, was granted tenure in the sociology department at the University of Wisconsin at Madison). One example from legal academia of a blogging success story is Orin Kerr, who began blogging at the Volokh Conspiracy while pretenured.

In fact, during the editorial process of this Article one coauthor, Tung Yin, received a positive faculty vote for tenure at the University of lowa.

25. See Solum, supra note 7 ("I also am familiar with several 'juniorish' (untenured or recently 


\section{WHAT COLOR IS YOUR BLOG: THE BLOGgING SPECTRUM}

An analysis of the risks and rewards of blogging would be incomplete without distinguishing among the different types of academic blogs that a law professor might want to create. Not all academic blogs are the same; in fact, law professors have created a wide variety of blogs. ${ }^{26}$ Because the type of blog that a pretenured professor chooses to create impacts that professor's cost-benefit analysis, a brief categorization of the legal blogosphere is necessary.

In the blogosphere, law professors participate in blogs that have a single, law-related purpose and in blogs that have no legal content whatsoever. Most blogs, however, fall in between those extremes on a spectrum from near-scholarship to not scholarly at all. The scholarly nature of a blog can add to both the riskiness of the blog and also to its rewards.

\section{A. Single-Purpose Legal Blog}

Few blogs can be categorized as blogs with a purely law-related profile. These blogs do not stray from their purpose and riff about popular culture, rant about an annoying grammatical mistake on a billboard, or report that an alma mater has won the Rose Bowl. Among these rare blogs is Lawrence Solum's Legal Theory Blog, ${ }^{27}$ which combines reviews of new law review articles with occasional analyses of troublesome legal theories and a weekly entry in the Legal Theory Lexicon. ${ }^{28}$ One recent trend has bloggers disaggregating once-general blogs into specific categories. For example, Stephen Bainbridge separated his blogging activities into three blogs: one on wine, one on personal topics, and one single-purpose legal blog, BusinessAssociations.com. ${ }^{29}$ In addition, the Law Professor Blogs ${ }^{30}$ strive to be aggregators of current topics in the various areas represented and not vehicles for the individual editors to opine on a wide range of topics.

\footnotetext{
tenured) legal academics who have gotten 'ahead of the curve' through excellent blogging.").

26. Census 4.3, supra note 1 (noting that law professors participate in no fewer than 117 blogs).

27. Legal Theory Blog, http://lsolum.blogspot.com/.

28. Legal Theory Lexicon, http://egaltheorylexicon.blogspot.com/.

29. http://www.businessassociationsblog.com/ (last visited Jan. 8, 2006).

30. Law Professor Blogs, http://www.lawprofessorblogs.com/.
} 


\section{B. Legal Blog with Personality}

The next category of blogs, for our purposes, are blogs that hew fairly closely to legal topics, but allow their authors to show their personalities both in their legal posts and in posts that have little or nothing to do with the law. Authors on these blogs regularly weigh in on law firm life, academic life, and popular culture. Most legal blogs seem to fall in this category, including Volokh Conspiracy, ${ }^{31}$ PrawfsBlawg, ${ }^{32}$ Concurring Opinions, ${ }^{33}$ and Conglomerate. ${ }^{34}$

\section{Personality Blog with Legal Aspects}

The reverse of the last category is a category for blogs that generally are outgrowths of the law-professor-author's personality, with occasional posts about legal topics. Other posts may be on political topics, popular culture, or personal issues, and these posts make up more than half of the number of posts on the blog. Blogs that fit this profile include Althouse ${ }^{35}$ and The Yin Blog. ${ }^{36}$

\section{Non-Legal Blog}

At the far end of the spectrum are the rare blogs that are authored by law professors but are intentionally unrelated to law, legal practice, or legal academia. One example of this type of blog is Nina Camic's Other Side of the Ocean. ${ }^{37}$

\section{QUANTIFYING THE DOWNSIDE OF BLOGGING}

The main risks of blogging for pretenured professors are spending an inappropriate amount of already scarce time on blogging activities, sparking controversy by taking unpopular positions or by knowingly or unknowingly making statements that offend others, and presenting an unflattering portrait of one's intellectual abilities.

31. The Volokh Conspiracy, http://www. volokh.com/.

32. PrawfsBlawg, http://prawfsblawg.blogs.com/.

33. Concurring Opinions, http://www.concurringopinions.com/.

34. Conglomerate, http://www.theconglomerate.org/.

35. Althouse, http://www.althouse.blogspot.com/.

36. The Yin Blog, http://yin.typepad.com/the_yin_blog/.

37. Other Side of the Ocean, http:/ninacamic.blogspot.com/. 


\section{A. Time}

Some of these potential pitfalls can be avoided by the choice of blog format. For example, near-scholarship blogs are incredibly time consuming, and even legal blogs with personality require a great deal of attention. A thoughtful analysis of yesterday's Supreme Court opinion will require spending time with the opinion, with precedents, and with your own text. This post will require some amount of citation and support. In addition, if the blog allows comments, then the poster will have to spend time responding to the (hopefully) relevant questions and counterarguments of readers. The poster may also receive e-mails from readers that require a response. To regularly compose and post these types of nearscholarship entries requires daily monitoring of current events and happenings in one's field. If a law professor uses a blog to advance opinions on current topics in a legal field, then that professor must spend substantial time ensuring that her knowledge of her field is current and upto-date. On the other hand, maintaining a blog that is not primarily devoted to legal topics may require much less time and diligence. Although blogging about one's travels or a great new book will necessarily take time, these posts may be entered at one's leisure and generally will not require putting aside an afternoon or evening because a New York Times e-mail alert reports breaking news.

Other variations on the blogging theme can increase or decrease the risk to a pretenured blogger's career. For example, a law professor may choose to blog alone or on a group blog, and each type has advantages and disadvantages. Generally, to attract and maintain a readership, a blog must frequently create new content. The blogs with the highest readership post new content on a daily, or almost daily, basis. For a solo blogger, singlehandedly providing all of the content creates great demands on one's time. The pressure to provide fresh content may vary depending on the goals and objectives of the blog, but shouldering one hundred percent of the blogging load will necessarily be a greater time commitment than being part of a larger group. ${ }^{38}$ Of course, being part of a group blog, in which the other bloggers are committed to increasing readership and posting high-

38. For example, Orin Kerr, an established and frequent poster on Volokh Conspiracy, began a solo blog on March 2006, OrinKerr.com, which was designed to be a solo, single-purpose legal blog. In August, Professor Kerr announced a hiatus because "[u]nfortunately, I don't think I'm going to have the time to keep up the solo blog as much as I would like, either from the standpoint of daily posts or moderating comment threads." See August Solo Blog Hiatus (Interpret: I'm Back Blogging at the VC), http://www.orinkerr.com/2006/08/13/august-solo-blog-hiatus/ (last visited Jan. 8, 2006). 
quality legal analyses on a regular basis, may create a different type of time pressure. However, if a pretenured law professor is interested in creating a high-maintenance, near-scholarship blog, then creating a group blog with several other like-minded bloggers would make that goal more easily achievable.

From time to time, the topic of blogging and gender arises,${ }^{39}$ and much of that discussion usually centers on whether female professors, who may already be trying to balance work and family obligations, can afford to spend time blogging. ${ }^{40}$ Some have suggested that these time constraints account for the fact that more male law professors than female law professors blog. ${ }^{41}$ In fact, Professor Jessica Silbey, of the blog LawCulture, ${ }^{42}$ has opined that the "economy of time" creates a blogosphere that is dominated by the privileged few with excess time resources, and that this dynamic works against women, who will not be able to exploit the career advantages of blogging. ${ }^{43}$ However, blogging may be technology that expands female law professors' career opportunities precisely because it requires a different sort of time. Previously, the best way to interact and network with senior scholars was to travel them. Traveling is a considerable drain on professors who are primary childcare givers. Blogging allows young parents to interact with scholars across the country from the comfort of their couches, while children sleep, watch Backyardigans, or have a snack.

\section{B. Being Controversial}

In addition, the scholarly nature of a blog may create a risk that a pretenured blogger may wittingly or unwittingly spark controversy by proffering a certain opinion or by disagreeing with the analysis of a more senior professor, reader, or blogger. The opportunity for annoying others or inadvertently offending someone increases if the blogger posts in an

39. Post of Christine Hurt to Conglomerate, http:/www.theconglomerate.org/gender_issues/ index.html (Jan. 8, 2006).

40. But see Post of Marcy Peek to Prawfsblawg, available at http:/prawfsblawg.blogs.com/ prawfsblawg/2005/10/why_the_gender_html (Oct. 12, 2005, 4:44 a.m.) (noting other reasons such as risk-aversion as to the gender imbalance).

41. Census 4.3, supra note 1 (reflecting that as of March 2006, the legal blogosphere comprised fifty-eight female professors and 177 male professors).

42. LawCulture, http://lawculture.blogs.com/.

43. Posting of Jessica Silbey to LawCulture, http:/lawculture.blogs.com/lawculture/the blogosphere/index.html (Apr. 28, 2006, 6:09 p.m.) ("Thinking more cynically, I gather the economy of time as a measure of successful blogs may also translate into a reified privilege based on class and/or gender status, which works to entrench working mothers as second-class professionals."). 
area in which others hold fairly passionate beliefs. ${ }^{44}$ Pretenured bloggers may find that posting on constitutional law topics, for example, may engender more heated exchanges than posting on corporate taxation. Also, some legal topics, such as abortion and same-sex marriage, invite not only legal analysis but political and social commentary. Blogging on innately political topics, such as the Iraq war, Abu Ghraib, political elections, domestic intelligence gathering, and even Supreme Court nominations can be risky, even though the topics fall within one's area of legal expertise.

Legal topic blogs, as well as personality-driven blogs, can easily stray into political issues. For a pretenured professor, the risks associated with political posts may outweigh any of the perceived career benefits of finding one's political voice in the blogosphere. Some bloggers may naturally be passionate about political issues and may feel that the importance of contributing to a national dialogue, or even merely venting, is worth any of the career risks of doing so. However, launching into a political discussion in the blogosphere is different from discussing politics with colleagues in the hall. Blog posts may be more ephemeral than letters to the editor, but they are nevertheless memorialized for future retrieval and may be forwarded to unpredictable recipients now and in the future. Being uncircumspect regarding political matters on a blog may come back to haunt a pretenured professor at a later time when she realizes that her "paper trail" is a bit longer than expected.

That being said, some bloggers have gained much respect from colleagues by being imminently reasonable in their political commentary. The blogosphere and the larger community greatly benefit from informed blogging on political issues that generally garner knee-jerk reactions from media pundits and politicians. However, this type of blogging requires a great amount of discipline and self-awareness. Pretenured bloggers should proceed in this area with caution.

44. Following the conference for which this article was written, a controversy arose surrounding Juan Cole, a tenured professor of Modern Middle East and South Asian History at the University of Michigan. Although Yale had expressed a desire to hire Professor Cole away from Michigan, that appointment was rejected by a senior committee. Although neither Cole nor Yale articulated a reason for the sudden change of heart, the blogosphere speculated that Cole's very popular blog Informed Consent, which had made Professor Cole very well known for his views against the war in Iraq, may have made Yale administrators nervous. The Chronicle on Higher Education ran a forum in which well-known bloggers, including Ann Althouse and Daniel Drezner, rehashed the topic of the dangers of blogging. See Can Blogging Derail Your Career?: 7 Bloggers Discuss the Case of Juan Cole, Chron. Higher EduC., July 28, 2006, at B6. 


\section{Being Wrong}

Finally, an outspoken blogger on legal issues runs the risk of simply being wrong. Law review articles are created over long periods of time, undergoing many rounds of edits before being turned over to eager law review editors who will vet the articles even more. Blog posts are created in Internet time, and bloggers must throw out their ideas with only minutes or possibly hours of reflection and review. In addition, bloggers often post on topics that are not in their core areas of expertise. Therefore, the potential for posting a legal argument with a critical flaw or an incorrect statement of the law is quite high. Having another blogger characterize one's argument as being "misguided" or "lacking" causes a certain amount of discomfort-having another blogger point out that one has misstated the law causes almost physical pain. Although readers may disagree on a post involving sports, movies, or parenting, these types of posts typically would not cause a law school colleague to question a blogger's ability to produce scholarship or to teach in a particular area. However, frequently creating legal posts that contain errors or dubious arguments cannot help one's reputation either in one's own institution or in the academic world at large.

\section{Persona Questions}

At some point, bloggers must confront their blogging persona. For many, one's persona, or tone, comes quite naturally without conscious thought. Other bloggers make a decision as to whether their tone will be casual, detached, adversarial, professional, objective, or persuasive. For pretenured bloggers, the choice of tone can ameliorate or exacerbate some of the risks involved in becoming a public blogging figure. Unfortunately, although a great blogging tone is an asset and an annoying blogging tone is a liability, most people are imperfect judges of their own blogging personas. ${ }^{45}$

\section{E. Franchise Blog v. Entrepreneur Blog}

For the law professor intent on creating a blog, at least two infrastructure options are available. First, the professor may create a blog

45. As Carrie Fisher's character in When Harry Met Sally says, "Everybody thinks they have good taste and a sense of humor but they couldn't possibly all have good taste." See When Harry Met Sally ... (Castle Rock Entertainment 1989). 
out of scratch or out of thin blogospheric air. This professor must choose a platform, create a template, and fine-tune the look and operability of the blog. Contemporaneous with launching the blog, the professor must market the blog with e-mail announcements to other bloggers, listservs, and colleagues. As the venture progresses, the blogger will have to spend some amount of time marketing the blog, responding to technical problems, and attending to administrative duties of maintaining the blog.

Or, the professor may choose to become part of the Law Professor Blogs Network (Law Prof Blogs) by either proposing a new topical blog or by joining an existing blog. ${ }^{46}$ The professor would not have to invest resources in starting up the blog, and marketing is built into the network.

Each of these options has differing risks and rewards. The Law Prof Blogs franchise minimizes some of the time-commitment risks by offering a turnkey operation. In addition, the Law Prof Blogs seem to enforce and encourage self-monitoring to ensure that posts are on topic and do not stray into riskier, more controversial areas. Starting one's own blog is riskier because of the time commitment and the potential for straying into controversial, wacky, or inappropriate topics or an inappropriate blog "voice." However, creating one's own blog has the rewards available to all entrepreneurs, including unlimited upside. The blogger has the opportunity to create a blog that hits exactly the right tone and has interesting and creative content. Should that perfect confluence of events happen, then the individual blogger, or bloggers, will get the credit for that blog. The blog will be associated with its authors, not with its network. As with small businesses, the franchise offers capped costs, but also capped profits. ${ }^{47}$ The personal blog, however, offers both unlimited pitfalls and unlimited reward.

\section{ALL PUblicity IS GoOD PUBLICITY: BlogGing AS EXPOSURE}

Just as the risks of the various types of blogs differ, the rewards to the blogger differ depending on the type of blog. Blogging is a great way for pretenured professors to network with other professors in their areas of

46. Law Professor Blogs, http://www.lawprofessorblogs.com.

47. In this discussion, we are focusing on non-monetary rewards. However, the potential for actual profits does exist in the blogosphere. Some blogs accept advertising, which generates some revenue. The very rare blogger has obtained commercial sponsorship or been lured to a commercial website, thus turning blogging efforts into profits. Obtaining commercial sponsorship, although rare, would be analogous to a small business eventually going public, a possibility not available to franchisees. In the Law Prof Blogs franchise, the franchise has corporate sponsorship, and the division of profits is unknown to the authors. 
teaching. Professors who traditionally would be overlooked for conference panels and presentations because of their geographical location, junior status, or institution can now disseminate their ideas to senior colleagues they may have never met. From a career standpoint, creating a wellregarded near-scholarship blog can generate almost unquantifiable rewards. Like producing good scholarship, high-profile blogging in a subject area is a great way to increase your reputation as a scholar. While less risky, hosting a blog on non-legal subjects may not generate career rewards. Of course, participating in a non-legal blog may have other rewards not discussed in this Article.

\section{A. Good Exposure}

The goal of a junior professor who wishes to advance in academia is to be recognized nationally as a capable scholar. Pretenured professors at highly ranked institutions have a built-in infrastructure that allows them to build their reputations. With large development budgets, regular in-house workshops by faculty from other schools, the ability to host conferences, and access to well-known scholars down the hall, these lucky few are able to network with influential professors in their fields with ease. For these professors, the additional benefits of blogging may not be worth the risks. For junior law professors at lower-tiered schools without access to this infrastructure, however, blogging may create opportunities for just this kind of networking.

For all law professors, blogging may produce recognition by those outside legal academia. Legal academic blogs are read not only by law professors and law students, but also by lawyers, other academics, lay persons, and reporters. A junior faculty member who becomes well known and respected on a particular legal topic can receive invitations to speak on panels or to present papers at conferences as a result of blogging exposure, as has happened to both of this Article's authors. Bloggers have been known to be contacted by reporters from national publications and publications outside of the bloggers' geographic area because the reporters' research (read: Googling) lead them to blogposts. This type of contact may result in the blogger adding to the background of a piece or being quoted. Some bloggers have even used these contacts to open doors for publishing opinion pieces in newspapers. In addition, bloggers may receive calls from attorneys that are looking for expert witnesses and who have discovered the bloggers through their posts. 


\section{B. Bad Exposure (and How to Avoid It)}

Unfortunately, for every one hundred blogposts that a pretenured professor writes, not all will enhance readers' opinions of that professor. As stated earlier, bloggers risk criticizing others who do not take criticism well, publishing half-baked ideas, and making careless errors. Often, a junior professor will become embroiled in a blogospheric debate that the professor just cannot win. By extending these heated exchanges, the junior blogger may start to look rather silly. Notably, the junior blogger risks looking silly, or just plain wrong, in front of not only anonymous general readers, but also future members of promotion and tenure committees.

However, this type of negative exposure may have a silver lining. Just because a blogger's point of view does not emerge as the most enlightened or reasonable does not mean that the blogger's career is over. Unlike law review articles, which are published with many months in between volumes, blogposts proliferate on a daily basis. A foolish post on Monday may be forgotten if followed by quite intelligent posts on Tuesday and Wednesday. In addition, months later, even a fellow law professor-reader may recall your name and associate your name with blogging on a particular topic, but not necessarily recall that others quickly pointed out errors in your posting. As the saying goes, sometimes all publicity is good publicity.

Much of the risk of bad exposure can be reduced by having a likable persona. Most readers will forgive a blogger for being wrong if a blogger is willing to change her views to accommodate the more intelligent comments of others. Bloggers can reduce the sting of being wrong if they respond to comments, keep an open mind, and keep a congenial tone. Often, commenters do not censor themselves very well and exhibit rather uncollegial tendencies. Anonymous commenters sometimes make almost irrational comments that are off-topic or merely ad hominem attacks. Bloggers should decide at the outset how to respond to these commenters, if at all. If a rude commenter has a valid point (or almost has a valid point), a blogger who responds rationally will gain the respect of other readers. If a rude commenter does not have a point but is just ranting, then the best tactic may be ignoring the commenter. Although all academics feel the need to have the last word, in blogging discretion is often the better part of valor in this regard. 


\section{BLOGgING AND ACADEMIC WRITING}

The connection between blogging and academic writing merits a closer review, because the time-blogging-reward tradeoff has particular ramifications in this context.

\section{A. Does Blogging Take Away Time from Academic Scholarship?}

As discussed earlier, steady and regular blogging can be time consuming, particularly if one opts for a near-scholarship blog format that requires at least daily posting. This time must come from somewhere, and a junior scholar who is considering whether to start blogging might well wonder whether blogging will eat into time for scholarship - a view that skeptical senior colleagues may well hold.

There are, however, a number of countervailing points. First, to the extent that blogging may take time away from scholarship, it is at worst a hobby - an activity that the scholar finds personally enjoyable but that does not advance his or her professional career. Unless one is committed to spending every waking moment devoted to scholarship (or teaching or service), blogging need not be time taken away from scholarship. Instead, it can compete for free time with pleasure reading, watching television, spending time with friends or family, and other such activities. This is not to say that blogging will not inhibit scholarship, only that it need not, if the blogger is disciplined about time management.

Second, depending on the nature of what one blogs about, blogging may be a form of pre-scholarship. For example, a blog post may serve as a rough draft of an abstract for a future article. As an added benefit, a public posting may inspire the blogger to articulate an idea with a greater degree of precision than the blogger might in a document for personal use, thereby improving the blogger's article concept. Furthermore, there is the possibility of receiving relatively quick feedback, either in the form of comments to the blog post or posts at other blogs. Even if the feedback convinces the blogger that the idea is untenable, the blog post has served a useful purpose by saving the blogger from sinking more time into a hopeless project.

Third, the more that one blogs on legal issues within one's research area, the more that blogging may help in keeping up on current events and developments in that area. This may be particularly true if academic blogging becomes more prevalent than it is today, such that real-time 
discussions of legal issues migrate from hallways and e-mail listservs to blogs. ${ }^{48}$ If this were to occur, reading other blogs may become more important than it currently is, and a blogger's interaction with other bloggers can only deepen the blogger's field of knowledge.

Fourth, blogging has the incidental benefit of serving as a virtual filing system of news stories, documents, press releases, and relevant blog posts that a blogger runs across and links to. In other words, if you run across an interesting document posted somewhere on the Internet, you can write a short blog post linking that document, and down the road, if you need to find the document again, all you have to do is search for that blog post. ${ }^{49}$ While such a virtual filing system might be seen as unnecessary because you would likely have printed the document in the first place, it at a minimum provides a backup in the event that the hardcopy is lost or misplaced.

There is a final, perhaps underappreciated point about the bloggingtime tradeoff: the concerns about the time that blogging consumes are generally relevant once one starts reading blogs, regardless of whether one actually blogs. ${ }^{50}$ Blog reading can be addictive and enormously time consuming, especially if one interacts with a number of blogs through comments. Therefore, if one views blogging as a waste of time - or at least, a use of time that would be better spent on scholarship - the only way to be sure to avoid diverting time from scholarship is by not reading blogs at all. While this would be an understandable reaction, the authors believe that a blanket avoidance of all legal blogs would be unfortunate, as it would mean missing out on a vibrant and exciting new form of legal expression.

48. The blogosphere has numerous examples of blogs dedicating space for a day or a number of days to a particular topic, with numerous posters engaging in an interative dialogue. One example was a planned forum on the Delaware Chancery Court's opinion in In re Disney Co. Derivative Litigation, issued in August 2005. See Posting of Gordon Smith to Conglomerate, http:/www.theconglomerate .org/2005/08/welcome_to the_html (Aug. 10, 2005). The authors of Conglomerate arranged for various guests to receive the opinion directly from the court on the day the opinion was released and then begin blogging immediately about its contents and consequences. The forum was then cited in the popular media, including in the Wall Street Journal and the New York Times. Because of the success of the forum, four of the posters arranged to watch the webcast of oral arguments of the appeal to the Delaware Supreme Court and post their impressions on the blog again. See Posting of Gordon Smith to Conglomerate, http://www.theconglomerate.org/2006/01/disney_oral_arg.html (Jan. 20, 2006).

49. Some blogging interfaces provide tools for searching internally within the blog. Absent that, Google or other such search engines might be effective. And, with the ability to categorize blog posts, a blogger could find the particular blog post by searching within the category archives.

50. Indeed, a number of bloggers were inspired to blog after reading one or more blogs. 


\section{B. The Impact of Blogging on Academic Writing}

An additional consideration is how blogging affects one's academic writing. At one level, the more writing that one does, the better one's writing becomes. Obviously, the connection between academic writing and blogging is strongest where the blogging is on legal matters. Yet, even nonlegal blogging can hone one's academic writing, if one brings to bear the general analytical tools that would be used on a legal matter. Some hallmarks of good academic writing - careful and evenhanded evaluation of relevant evidence, logical conclusions, and persuasive advocacy can show up in writing about a variety of nonlegal matters, from arguments about which baseball player is most deserving of the Cy Young Award to why The Matrix's explanation of how the computers were using humans as an energy source actually violates the Second Law of Thermodynamics.

While the benefit of blogging on the quality of one's writing is easy to see, its impact on the rigor of one's writing, in terms of source citation, is less certain. On the one hand, there is a general norm in the blogosphere of linking to primary or secondary sources where possible. ${ }^{51}$ This norm is at least as rigorous as the norm in academic writing of using footnotes to cite relevant sources; however, it is much easier for a blog reader to click a link to see the source than it is for a law review article reader to find a case or other source on a library bookshelf. Even sources available on Westlaw or Lexis still require that the reader have an account with the appropriate search service, sign on, and locate the case or source. ${ }^{52}$

On the other hand, though, this is merely a norm. Unlike a traditional law journal article, where, prior to publication, law students assiduously verify that cited sources actually support the assertions made, a blog post is published when the blogger clicks on "publish." Thus, blogging might actually lead a blogger to develop lazy habits that could carry over into traditional scholarship. Though such bad habits would be corrected during the publication process of an article, it could well impact the quality of the

51. See Posting of Larry Ribstein to Ideoblog, http://busmovie.typepad.com/ideoblog/2005/07/ blogging_and_th.html (July 21, 2005, 8:41 a.m.) (arguing that the general scholarship norms of surveying the prior literature before writing and then citing to that prior literature should also apply to blogposts). For a contrasting view, see also Posting of Will Baude to Conglomerate, http://www. theconglomerate.org/2005/07/ethics_and_pree.html (July 21, 2005) (arguing that the high costs inherent in doing a blogospheric preemption check are not justified by the dubious benefits and will act to deter academic bloggers).

52. Furthermore, while law professors and law students have free access to Westlaw and Lexis, anyone else would generally have to pay to use those services to look up sources cited in law review articles. 
article at the time it is submitted to the law journals, thereby affecting the placement of the article.

\section{EXPlaining Blogging to Your TENuRE COMMITTEE}

While a blogger may come to view blogging as semi-scholarship as well as a way of maintaining and improving his or her academic writing, at the end of the day the blogger must confront the question of whether blogging can be explained to one's tenure committee as a productive academic endeavor.

The pretenured law professor is likely to be thinking about the "tenure file" from the first day on the job. Therefore, the decision whether to begin a blog necessarily triggers the question of where, if at all, blogging fits into the tenure file.

Tenure standards at law schools typically consist of three elements: scholarship, teaching, and service. Tenure standards typically do not foreclose the inclusion of book chapters, books, or treatises as scholarship, and therefore, one might well wonder whether blogging could be counted as scholarship.

This is not to say that legal blog posts can never contain substantive legal analysis. For one thing, the fact that blogs can be published virtually instantly, while law review articles typically require several months (at a minimum), makes the former far more suitable for real-time discussion of, for example, recent Supreme Court cases or legal developments. A good example is Sentencing Law and Policy, ${ }^{53}$ which garnered much attention at its inception for its continuing coverage of the response of courts to the Supreme Court's decision striking down the mandatory application of the federal sentencing guidelines. The utility of case updates and discussions would have been significantly reduced had there been a lag-time of several months before publication. ${ }^{54}$

However, the baseline against which other forms of scholarship is measured is the fifty- to one-hundred-page law review article that is packed with copious footnotes. ${ }^{55}$ Much has been said about traditional law

53. Sentencing Law and Policy, http://sentencing.typepad.com.

54. One indication of the substantive quality and depth of the posts on Sentencing Law and Policy is the fact that it has been cited, according to a study by a law student blogger, twenty-one times in seventeen different judicial opinions, including a dissenting opinion by Justice Stevens. Law Blog Metrics [formerly 3L Epiphany], http://3lepiphany.typepad.com/31_epiphany/cases_citing_le.html (Apr. 15, 2006).

55. For example, the University of Iowa College of Law tenure standards contain a quantitative requirement of at least "two substantial and analytical scholarly works or the equivalent thereof," with 
review articles (and not all of it flattering), but that is a debate beyond the scope of this Article. ${ }^{56}$ So long as the scholarship component of law school tenure standards continues to measure "scholarship" against traditional law review articles, blogging is going to be difficult to characterize as academic scholarship for tenure review purposes. Most blog posts are less than a computer screen long making them perhaps equivalent in substantive content to an op-ed article, or perhaps postings to academic listservs. $^{57}$

For example, consider a typical blog post on the aforementioned Sentencing Law and Policy, discussing two recent Eighth Circuit sentencing decisions, noting the potential gender disparity in sentencing, and closing with this bit of analysis:

I encourage everyone who thinks the federal sentencing system does a good job achieving uniformity to compare what happened to Mrs. Bistrup and Mr. Givens. Mrs. Bistrup gets merely probation after being convicted of multiple fraud counts at trial and facing a guideline range of 37-46 months; meanwhile, Mr. Given pleads guilty, faces a lower guideline range, but the Eighth Circuit rules that a year of house arrest, restitution of over $\$ 1.2$ million, and additional sanctions are too lenient. Hmmm. . . . ${ }^{58}$

This is a provocative post that raises a number of serious questions about whether there exists significant disparity between the sentencing of men versus women (one case involved husband and wife codefendants who received different sentences) and whether the sentencing guidelines can achieve their stated goal of reducing sentencing disparity. But it is a post that raises questions without answering them. No doubt, these cases - and the discussion of them - would be useful parts of a traditional article that would examine and reach some conclusion, and there is definite value to the academic and practicing communities in having these thoughts posted. By themselves, however, these thoughts would not rise to the level of traditional scholarship.

substantial works defined as "equivalent to a major law-review article." See College of Law Tenure Standards and Procedures $\$ 2 \mathrm{~B}(2)$ (Univ. of Iowa 2004), available at http:/www.law.uiowa.edu/ documents/coltenure.pdf.

56. In defense of the traditional law review article as the baseline, there is something to be said for a bright-line standard in which publication opportunities are plenty and in which the time cycle, while glacial compared to blogs, is much faster than that of books.

57. A prime example of legal blog posts that are extremely long by blogosphere standards is the weekly Legal Theory Lexicon post at Legal Theory Blog, http://legaltheorylexicon.blogspot.com/.

58. Posting of Douglas Berman to Sentencing Law and Policy, http:/sentencing.typepad.com/ sentencing_law_and_policy/2006/04/gender_disparit.html (Apr. 11, 2006, 12:09 p.m.). 
Nor is blogging likely to be viewed as teaching. Well-written substantive blog posts on matters of law can, of course, educate readers, but this is education that takes place outside the classroom. It does not involve the sort of interaction between professor and student that, rightly or wrongly, characterizes legal education (although something similar to such interaction can take place in the comments section, if the blog enables comments). Most importantly, it is not teaching that can be connected to the law school.

To the extent that the tenure standards at the blogger's institution do not include a "catch-all" category, ${ }^{59}$ blogging would then be relegated to the service category, which may itself be a "catch-all". Either way, it may be best to view blogging as a supplement to the three elements of the tenure file, rather than as a substitute for one or more of them.

\section{CONCLUSION}

Although our conclusion has been somewhat refined after hearing discussion of this paper at the panel, Bloggership: How Blogs are Transforming Legal Scholarship, our actions as bloggers seem to suggest to ourselves and others that we believe that the benefits of pretenured blogging outweigh the costs in our individual situations. Other would-be bloggers will have to perform their own analysis. Unfortunately, this analysis must be done with an unflinching look at one's own ability to self-monitor, self-discipline, and manage time. Also, blogging candidates should determine whether blogging offers benefits that one's own institution cannot offer. Pragmatic professors will also consider whether the choice of blogging form can decrease the risks or increase the benefits. For the majority of pretenured law professors, blogging may be a great way to become a part of the dialogue in a given area. And is that not why we became law professors in the first place? ${ }^{60}$

59. For example, one of our home institutions (Marquette University) includes such a catch-all category, while the other (the University of lowa) does not.

60. Perhaps Professor Cole articulated this philosophy the best in his response to the controversy that suggested his meteoric career had been thwarted by his political blog: "The question is whether Web-log commentary helps or damages an academic's career. It is a shameful question. Intellectuals should not be worrying about 'careers,' the tenured among us least of all." Juan R.I. Cole, Juan R.I. Cole Responds in Can Blogging Derail Your Career?: 7 Bloggers Discuss the Case of Juan Cole, CHRON. Higher EdUC, July 28, 2006, at B9. 
